\title{
Joint Defense or Research Joint Venture? Reassessing the Patent-Challenge-Bloc's Antitrust Status
}

Joseph S. Miller

University of Georgia School of Law, getmejoe@uga.edu

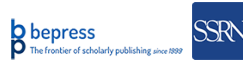

\section{Repository Citation}

Joseph S. Miller, Joint Defense or Research Joint Venture? Reassessing the Patent-Challenge-Bloc's Antitrust Status , 2011 Stan. Tech. L. Rev. 5 (2011),

Available at: https://digitalcommons.law.uga.edu/fac_artchop/698

This Article is brought to you for free and open access by the Faculty Scholarship at Digital Commons @ University of Georgia School of Law. It has been accepted for inclusion in Scholarly Works by an authorized administrator of Digital Commons @ University of Georgia School of Law. Please share how you have benefited from this access For more information, please contact tstriepe@uga.edu. 


\title{
Stanford Technology Law Review
}

\section{Joint Defense or Research Joint Venture? Reassessing the Patent-Challenge-Bloc's Antitrust Status}

\author{
JOSEPH SCOTT MILLER *
}

Cite AS: 2011 StAN. TeCH. L. ReV. 5

http://stlr.stanford.edu/pdf/miller-joint-defense.pdf

* Professor, Lewis \& Clark Law School. (C) 2011 Joseph Scott Miller. Thanks to Josh Walker of the Stanford Intellectual Property Litigation Clearinghouse / Lex Machina for providing the patent litigation data discussed in Part I. 
TABLE OF CONTENTS

INTRODUCTION

I. THE PREVALENCE OF PLURAL ACCUSED INFRINGERS

II. FIRST PRINCIPLES: ANALYZING A PATENT-CHALLENGE-BLOC AS A RESEARCH JOINT VENTURE

A. Court Judgments of Patent Status and Scope are Inappropriable ...................................................10

B. Credibly Sharing Costs Solves the Appropriability Problem ..........................................................14

C. A Durable Patent-Defense Joint Venture Is Procompetitive ............................................................16

III. OLD BLUNDERS: MISTAKING A PATENT-CHALLENGE-BLOC FOR AN UNLAWFUL GROUP BOYCOTT.

\begin{abstract}
A patent challenger who defeats a patent wins spoils that it must share with the world, including all its competitors. This forced sharing undercuts an alleged infringer's incentive to stay in the fight to the finish-especially if the patent owner offers an attractive settlement. Too many settlements, and too few definitive patent challenges, are the result. I have argued previously that a litigation-stage bounty would help correct this tilt against patent challenges, for it would provide cash prizes to successful patent challengers that they alone would enjoy. Even the best-designed bounty, however, would likely fail to encourage patent validity challenges in all the cases where such encouragement would be salutary. Others have urged that, going forward, post-grant administrative review is a more promising approach to weeding out weak patents. A new post-grant review procedure, however, will do nothing to encourage worthy challenges to thousands of extant weak, overasserted patents.

This article explores another litigation-stage approach to overcoming the free rider problem that undercuts patent validity challenges-namely, strong-form joint defense agreements among multiple accused infringers. Strong-form agreements, which go beyond light coordination and information sharing, have long been condemned as unlawful buyers' cartels. The seminal case remains Jones Knitting Corp. v. Morgan. But current doctrine's condemnation trades on a category mistake rooted in a fatally simplistic view that patents are commodity property (rather than what they are, which is probabilistic exclusion rights). Contrary to conventional wisdom, a binding commitment among accused infringers jointly to fund a full challenge to patent infringement allegations is not, nor is it akin to, a buyers' cartel for buying commodities. Rather, it is a research joint venture, the goal of which is to generate valuable-but otherwise inappropriable-information about the patent's true validity or scope.
\end{abstract}




\author{
Calling a platypus a mammal doesn't change the fact that it lays eggs. But calling a particular \\ competitive practice by one name or another often has dramatic consequences for whether or not the \\ law permits it. ${ }^{1}$
}

The war of all against all is not a good model for any economy. Antitrust law is designed to ensure an appropriate blend of cooperation and competition, not to require all economic actors to compete full tilt at every moment. ${ }^{2}$

\title{
INTRODUCTION
}

A patent challenger who defeats a patent wins spoils that it must share with the world, including all its competitors. This forced sharing undercuts an alleged infringer's incentive to stay in the fight to the finish-especially if the patent owner offers an attractive settlement. Too many settlements, and too few definitive patent challenges, are the result. Specifically, as I have discussed previously, ${ }^{3}$ the Supreme Court's collateral estoppel decision in Blonder-Tongue Laboratories, Inc. v. University of Illinois Foundation ${ }^{4}$ makes it significantly harder for a successful patent attacker to recoup her investment in that successful attack: the invalidity judgment, once secured, benefits everyone. ${ }^{5}$ Moreover, having received a court judgment as a matter of public record, the prevailing challenger cannot keep it a trade secret for private advantage. ${ }^{6}$ We should thus expect patent validity challenges (and, to a lesser extent, patent scope challenges) to be undersupplied, absent a way for attackers with a common interest in defeating or limiting a patent to coordinate their efforts effectively.

The free rider problem that undercuts patent challenges, like other collective action problems, arises when people who would benefit from making an investment decide to hang back, hoping that someone else will shoulder the cost. Others make the same decision, and no one invests. One barrier to overcoming this dynamic is that it is difficult for people to make credible binding commitments that they will help share the full cost in question ${ }^{7}$ —in this case, the burden of invalidating a patent.

\footnotetext{
${ }^{1}$ Mark A. Lemley \& Christopher R. Leslie, Categorical Analysis in Antitrust Jurisprudence, 93 IOwA L. REV. 1207, 1210 (2008) (footnote omitted).

2 Polk Bros., Inc. v. Forest City Enters., 776 F.2d 185, 188 (7th Cir. 1985).

${ }^{3}$ Joseph Scott Miller, Building a Better Bounty: Litigation-Stage Rewards for Defeating Patents, 19 BERKELEY TECH. L.J. 667 (2004) [hereinafter Miller, Better Bounty].

4402 U.S. 313 (1971).

5 See Miller, Better Bounty, supra note 3, at 673-74, 677-80, 685-88; see also Mark A. Lemley \& Carl Shapiro, Probabilistic Patents, 19 J. ECON. PersP., Spring 2005, at 75, 76, 88 [hereinafter Lemley \& Shapiro, Probabilistic Patents] ("LL]itigating patent disputes to completion tends to generate positive externalities, by clarifying the limits of patent protection if the patent is upheld or encouraging wider use of the innovation if the patent is invalidated."; " $\Pi$ nvalidating a patent generates significant positive externalities, and activities that generate positive externalities are undersupplied. There are very strong reasons to believe that challenges to patents are undersupplied."). Interestingly, among the more than 25 law review commentaries on Blonder-Tongue that appeared from 1970 to 1975, only one-John A. Kidwell, Comity, Patent Validity, and the Search for Symmetry: Son of Blonder-Tongue, 57 J. PAT. OFF. SOC’Y 473, 488 (1975)-recognized that defensive nonmutual collateral estoppel discourages patent validity challenges: "[T] he alleged infringer's incentives to litigate the validity of the patent were materially reduced [by Blonder-Tongue] since his investment in a successful attack on the patent has become a public good. Any competitors have the benefit of the finding of invalidity without paying the costs of the litigation."

${ }^{6}$ Using private arbitration does not appreciably alter the result: The parties to an aribtral award in a patent infringement dispute cannot enforce that award until they file a detailed notice of the arbitration, including a copy of the arbitration award, with the Patent and Trademark Office. 35 U.S.C. SS 294(d), (e) (2002).

${ }^{7}$ Discussing the "prisoner's dilemma" and "levees and floods" scenarios, Baird et al. highlight the key role that the inability to make credible commitments plays in causing unfavorable outcomes:

One would much rather not incur the cost of building a levee and suffer from a moderate flood than spend money on a levee and suffer from only slightly less flooding. Similarly, a prisoner would much rather spend two years in prison than six. These outcomes, however, are possible only when the players can reach a binding agreement. In both games . . the strategy combination the players choose leaves them both worse off than they would be if they could cooperate with each other.

DOUGLAS G. BAIRD ET AL., GAME THEORY AND THE LAW 34 (1994) (emphasis added); see also id. at 188 (“The prisoner's dilemma and the stag hunt are often used to capture the problem of collective action. Individuals have the private incentive to take
} 
93 The problem of binding commitments is quite difficult in patent infringement litigation. An outdated case imposing per se antitrust liability for a patent joint defense agreement, Jones Knitting Corp. v. Morgan, ${ }^{8}$ continues to deter firms from making credible commitments to share the full cost of a definitive patent challenge with one another. ${ }^{9}$ This is so notwithstanding the fact that Jones Knitting predates Blonder-Tongue by more than five years, and thus took place amid significantly different competition-structuring ground rules for reaping the returns of a successful patent challenge.

I have argued elsewhere that a general litigation-stage bounty would correct current doctrine's structural tilt against patent challenges. Such a bounty would provide cash prizes to successful patent challengers that they alone would enjoy. ${ }^{10}$ Others have proposed litigation-stage fee-shifting ${ }^{11}$ and examination-stage bounties ${ }^{12}$ to address the Blonder-Tongue problem. Even the best-designed bounty, however, may fail to encourage patent validity challenges in all the cases where such encouragement would be salutary. Moreover, the delay in patent reform legislation over the last several years ${ }^{13}$ suggests that Congress cannot presently make major changes to the Patent Act. Others urge that, given the perverse litigation incentives under current law, an administrative post-grant review mechanism is a more promising approach to weeding out weak patents than is a litigation-stage approach. ${ }^{14}$ Post-grant-review reform is bogged down with the rest of patent reform.

There is another litigation-stage method available to address the structural tilt against robust patent challenges. It requires doctrinal, rather than statutory, change. Specifically, the courts-with an assist from the antitrust enforcement agencies through such mechanisms as business review letters ${ }^{15}$ - should dump Jones Knitting as a misguided relic fatally undermined by later developments. The free rider problem Blonder-Tongue created, and the anticompetitive effects of patents licensed far out of proportion to their minimal strength, justifies allowing a group of alleged infringers to make binding commitments to one another to share the full cost of a patent challenge to final judgment and through any appeal. Specifically, the courts should construe $\int 1$ of the Sherman Act to permit alleged infringers to form a patent-challenge-bloc research joint venture wherein each member agrees, at a

actions that are not in their joint interest. These two-by-two games are emblematic of the problem faced by a large group of individuals who cannot enter into binding agreements with one another.").

8244 F. Supp. 235 (E.D. Pa. 1965), aff'd in relevant part, 361 F.2d 451 (3d Cir. 1966). The bulk of the Third Circuit's decision in the case is devoted to the question whether the patent at issue was invalid; the district court had held that the patent was invalid, and the Third Circuit disagreed. 361 F.2d at 452-59. The Third Circuit's analysis of the patentee's antitrust claim occupied all of a paragraph, in which the court quoted liberally from the district court's decision. Id. at 459 .

${ }^{9}$ Prudent commentators naturally continue to cite the Jones Knitting case for the proposition that alleged infringers violate the antitrust laws if they jointly agree not to settle with a patentee. See, e.g., 2 ABA SECTION OF ANTITRUST LAW, ANTITRUST LAW DEVELOPMENTS 1133 \& n.392 (6th ed. 2007); 2 HerberT HOVENKAMP ET AL., IP AND ANTITRUST: AN ANALYSIS OF

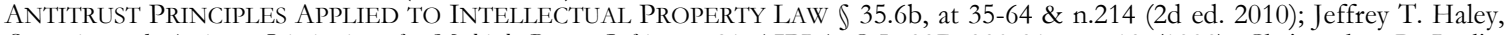
Strategies and Antitrust Limitations for Multiple Patent Infringers, 21 AIPLA Q.J. 327, 330-31 \& n.13 (1993); Christopher R. Leslie, Judgment-Sharing Agreements, 58 DUKE L.J. 747, 817 \& n.301 (2009).

More generally, conventional wisdom in the field is that patent joint defense agreements must be drafted with great care to avoid triggering antitrust liability. See Tony Dutra, Multi-Defendant Case Strategies Discussed in IPO's First 'TP Chat Channel' Webinar, 79 PAT., TRADEMARK \& COPYRight J. 50 (Nov. 13, 2009) (quoting antitrust lawyer M. Howard Morse: "It is okay for parties to agree to share costs, jointly hire a lawyer, and share joint defense material, he said. But it is definitely 'problematic' if the parties are competitors jointly exercising settlement authority. 'You can't agree on maximum future royalties or not to settle at all,' he said. He further suggested that, while the law is uncertain on some activities, parties should be cautious about [a] agreeing not to settle without notifying the others, $[\mathrm{b}]$ retaining joint counsel to handle settlement negotiations, and $[\mathrm{c}]$ sharing competitively sensitive confidential information, such as sales, price, cost, and profitability data, or certain technology information.").

${ }^{10}$ Miller, Better Bounty, supra note 3, at 705-31.

${ }^{11}$ Jay P. Kesan, Carrots and Sticks to Create a Better Patent System, 17 BERKELEY TECH. L.J. 763, 787-97 (2002). (2001).

${ }_{12}$ John R. Thomas, Collusion and Collective Action in the Patent System: A Proposal for Patent Bounties, 2001 U. ILL. L. REV. 305

${ }^{13}$ Dan L. Burk \& Mark A. Lemley, The Patent Crisis and How the Courts Can Solve It 3-4, 100-02 (2009); Liza Vertinsky, Comparing Alternative Institutional Paths to Patent Reform, 61 ALA. L. REV. 501, 502-03 (2010).

14 See Joseph Farrell \& Robert P. Merges, Incentives to Challenge and Defend Patents: Why Litigation Won't Reliably Fix Patent Office Errors and Why Administrative Patent Review Might Help, 19 BERKELEY TECH. L.J. 943 (2004) [hereinafter Farrell \& Merges, Incentives to Challenge]; Joseph Farrell \& Carl Shapiro, How Strong Are Weak Patents?, 98 AM. ECON. REv. 1347 (2008) [hereinafter Farrell \& Shapiro, How Strong Are Weak Patents?]; Jay P. Kesan \& Andres A. Gallo, Why "Bad" Patents Survive in the Market and How Should We Change?-The Private and Social Costs of Patents, 55 EMORY L.J. 61 (2006) [hereinafter Kesan \& Gallo, Why "Bad" Patents Survive].

15 See 16 C.F.R. $\ 1.1$ (2011) (FTC procedure); 28 C.F.R. \50.6 (2011) (Antitrust Division business review procedure); Ky P. Ewing, Jr., Thoughts on Seeking Business Reviews of Competitor Collaborations, 19 ANTITRUST 40 (2005). 
minimum, that (a) it will continue to shoulder its share of the full cost of challenging the patent even if it settles with (or takes a license from) the patentee, and (b) it will fully disclose all the terms of any settlement or license it may reach with the patentee. These terms undoubtedly hamper settlement compared to a world without the joint venture, but that world inefficiently props up bad patents. Additional venture-strengthening terms, such as a promise not to agree to a royalty rate below that of any similarly situated future licensee, may also prove to be procompetitive.

The key move is to recognize that the alleged infringers are not making an agreement simply to fix the price of a commodity input, as Jones Knitting framed the matter. Rather, the putative infringers are sharing the cost of testing the very premise that access to the technology in question requires any payment or permission at all. Testing that premise is critical, because the mere existence of an assertedbut-untested patent claim is far from a guarantee that payment is genuinely due. Owning a patent claim is not akin to owning a bushel of sugar beets or a barrel of milk, commodities one encounters in the buyer's-cartel cases. Patents are probabilistic: "The patent system does not grant an absolute right to inventors to exclude others from practicing their inventions, as many economic models assume. Rather, the patent system gives the patent holder a right to try to exclude others by asserting its patent against them in court." 16 And "[t]he risk that a patent will be declared invalid is substantial. Roughly half of all litigated patents are found to be invalid ...."17

But testing the patentee's right to exclude is not a trivial matter, in time or money. ${ }^{18}$ Thanks to Blonder-Tongue, the information that the joint-venture defense bloc seeks to obtain-the outcome of a definitive patent validity challenge-is less likely to be obtained by any one of them alone. Thus the durable patent-challenge joint venture agreement is reasonably necessary. ${ }^{19}$ Indeed, so long as each venture member is free to use the resulting patent status information as it sees fit, whether in independent negotiations with the patentee or in post-litigation decisions about the offering for

\footnotetext{
${ }^{16}$ Lemley \& Shapiro, Probabilistic Patents, supra note 5, at 95.

${ }^{17} \mathrm{Id}$. at 76.

18 See generally Jay P. Kesan \& Gwendolyn G. Ball, How Are Patent Cases Resolved? An Empirical Examination of the Adjudication and Settlement of Patent Disputes, 84 WASH. U. L. REV. 237 (2006).

${ }^{19}$ Commentators have long recognized that R\&D joint ventures can enhance competition by solving the free rider problem that undercuts investment in research outcomes that are not otherwise appropriable. See 1 ANTITRUST LAW DEVELOPMENTS, supra note 9, at 445-46 ("Research joint ventures often provide procompetitive benefits, such as sharing the substantial economic risks involved in $R \& D$. . . and overcoming the free-rider disincentive to invest in R\&D by including likely $R \& D$ end-users in undertaking the research efforts and sharing the costs." (footnote omitted)); 13 PHILLIP E. AREEDA \& HERBERT HOVENKAMP, ANTITRUST LAW $\$ 2115 \mathrm{a}$, at 110 (2d ed. 2005) (explaining that one "rationale for joint innovation is lacunae in the legal protection of intellectual property": "When intellectual property protection is lacking, the firm that innovates may be producing benefits for its rivals as well as for itself, thus reducing its incentives to innovate in the first place."); Joseph F. Brodley, Joint Ventures and Antitrust Policy, 95 HARV. L. REV. 1521, 1570-71 (1982) ("Research is by nature a high-risk activity. Yet, except when protected by patents or obscured by secrecy, the fruits of successful research can be appropriated by other firms with little, if any, cost outlay. . . . Joint research tends to solve [such] problems. The research risk to the individual firm is reduced because it is shared. In addition, joint research increases the return on research investment at the firm level, because more of those who profit from the research share in its costs."); Gene M. Grossman \& Carl Shapiro, Research Joint Ventures: An Antitrust Analysis, 2 J.L. ECON. \& ORG. 315,321 (1986) ("A research joint venture may provide a means to solve the appropriability problem associated with the production of knowledge. Firms that will inevitably share in the benefits of any research discovery can agree ex ante to share in its costs. ... In the extreme case, a joint venture form can facilitate the undertaking of socially profitable research projects that would otherwise not be pursued privately. In all cases, an RJV generates a social benefit whenever it allows a spillover externality to be internalized."); Joseph Kattan, Antitrust Analysis of Technology Joint Ventures: Allocative Efficiency and the Rewards of Innovation, 61 ANTITRUST L.J. 937, 943 (1993) ("The public good character of research and invention, with the attendant free rider problem, may lead to suboptimal investment in research and development of costly innovations. . . The joint venture format may offer at least a partial solution to the appropriability problem in the case of 'leaky' innovations. Rivals who otherwise may be reluctant to invest in an appropriable innovation might do so if potential free riders join them in the investment; a reduction in competition may thus increase incentives to innovate."); Michael L. Katz, An Analysis of Cooperative Research and Development, 17 RAND J. ECON. 527, 52728 (1986) ("Private incentives may be insufficient because of R\&D spillovers, whereby research done by one firm can be used by another firm even though the latter does not receive permission (i.e., purchase a license) to use the inventive output. A firm conducting $\mathrm{R} \& \mathrm{D}$ cannot demand payment from other producers who benefit from its R\&D through spillovers. Moreover, the innovator recognizes that its $R \& D$ efforts will strengthen its competitors, and this further dampens its incentives to conduct $R \& D$. ... A cooperative $R \& D$ agreement may serve as a mechanism that internalizes the externalities created by spillovers while continuing the efficient sharing of information. This internalization is accomplished by having firms commit to payments before the R\&D is conducted and, hence, before any spillovers can occur."); Gregory J. Werden, Antitrust Analysis of Joint Ventures: An Overview, 66 ANTITRUST L.J. 701, 703 (1998) [hereinafter Werden, Joint Ventures] ("In certain circumstances, joint ventures can also mitigate free-rider problems. . . [This] may be most significant for R\&D joint ventures. Patents and other intellectual property rights protect only some of the innovative output of an $\mathrm{R} \& \mathrm{D}$ effort, and what is not protected can be utilized by competitors of the innovator without compensation. The incentive to invest in R\&D can be enhanced by including within an R\&D joint venture firms that stand to gain from the venture's activities, even if they do not participate." (footnote omitted)).
} 
which the patented technology is an input, the agreement is no broader than necessary to correct the market failure at which it is aimed. In short, a binding commitment among alleged infringers to share the full cost of a court test of a patent's validity, with appropriate credibility-enhancing provisions, should not run afoul of the antitrust laws. ${ }^{20}$

My analysis proceeds as follows. Part I briefly reviews empirical evidence suggesting that a significant portion of patent infringement litigation involves plural accused infringers. Correctly assessing the antitrust limits on their ability to cooperate in challenging asserted patents is a genuine practical problem, not a philosophical frolic. Part II analyzes the prospects for a research joint venture in the form of a durable patent-challenge-bloc. It returns to first principles, analyzing the research joint venture without reference to the group-boycott frame Jones Knitting employed. Part III critiques Jones Knitting and its progeny, demonstrating that the group-boycott frame they usepredicated, as it is, on a simplistic equation of patent rights with commodity goods-obscures the efficiency gains that a well-structured patent-challenge-bloc can achieve.

\section{THE PREVALENCE OF PLURAL ACCUSED INFRINGERS}

Current law —or the conventional view of it, at any rate-hobbles plural accused infringers who share an interest in challenging a patent's validity from robustly funding a joint defense. The problem is not trivial. Given both the frequency of patent infringement litigation with multiple accused infringers, and the recently lowered barriers to declaratory judgment jurisdiction over infringerinitiated patent challenges, it is more important than ever that we establish the appropriate antitrust analysis of a durable patent-challenge bloc.

\$10 As to current frequency, the evidence is compelling. Plural accused infringers are the norm, and have been at least since 2000. Consider the data from the Stanford Intellectual Property Litigation Clearinghouse, in Tables 1 and 2 below. ${ }^{21}$ First, among all patent infringement suits in the U.S., from 2000 to 2009 inclusive, the average number of defendants per case was 2.44. And, over this decade, the trend has been upward. Second, the annual number of patent infringement suits filed with ten or more defendants has grown from just over 35 in 2000 to just over 135 in 2009, i.e., has almost quadrupled. As of this writing, there have already been 85 such suits filed in 2010.

${ }^{20}$ Cf. Grossman \& Shapiro, supra note 19, at 316 ("The fact that much of the output from an RJV is information implies that cooperative research ventures deserve especially lenient antitrust treatment.") (emphasis in original).

21 "The Clearinghouse collects every patent-infringement lawsuit filed since January 1, 2000, in searchable format, and links those suits to the patents in suit." John R. Allison et al., Extreme Value or Trolls on Top? The Characteristics of the Most-Litigated Patents, 158 U. PA. L. REV. 1, 5 (2009). The Stanford IP Litigation Clearinghouse is located at http://lexmachina.stanford.edu. 
Joseph Scott Miller: Joint Defense or Research Joint Venture? Reassessing the

Patent-Challenge-Bloc's Antitrust Status

Table 1: Average Number of Defendants per Patent Infringement Suit

\begin{tabular}{|c|c|c|c|}
\hline Year & \# of Suits & \# of Defendants & Average Defend's/Case \\
\hline 2000 & 2325 & 5301 & 2.28 \\
\hline 2001 & 2465 & 5570 & 2.26 \\
\hline 2002 & 2557 & 5236 & 2.05 \\
\hline 2003 & 2784 & 5876 & 2.11 \\
\hline 2004 & 2809 & 6337 & 2.26 \\
\hline 2005 & 2567 & 6012 & 2.34 \\
\hline 2006 & 2647 & 6375 & 2.41 \\
\hline 2007 & 2840 & 9042 & 3.18 \\
\hline 2008 & 2605 & 6857 & 2.63 \\
\hline 2009 & 2691 & 7481 & 2.78 \\
\hline Total & 26290 & 64087 & 2.44 \\
\hline
\end{tabular}

Data provided by the Stanford IP Litigation Clearinghouse / Lex Machina*

Table 2: Annual Number of Infringement Suits With Ten or More Defendants

\begin{tabular}{|c|c|}
\hline Year & \# With 10 or More Defendants \\
\hline 2000 & 36 \\
\hline 2001 & 44 \\
\hline 2002 & 35 \\
\hline 2003 & 49 \\
\hline 2004 & 54 \\
\hline 2005 & 60 \\
\hline 2006 & 73 \\
\hline 2007 & 120 \\
\hline 2008 & 112 \\
\hline 2009 & 136 \\
\hline
\end{tabular}

Data provided by the Stanford IP Litigation Clearinghouse / Lex Machina*

T11 In 2007, toward the end of the period covered by the foregoing data, the Supreme Court significantly changed declaratory-judgment-jurisdiction law in the context of patent infringement accusations. The case is MedImmune, Inc. v. Genentech, Inc. ${ }^{22} \mathrm{It}$ is now substantially easier for an accused infringer to initiate a court challenge to the validity or scope of an asserted patent. This doctrinal change brings added pressure to bear on the question whether the Sherman Act permits durable patent-challenge blocs.

I12 The MedImmune case itself dealt with the different question whether a patent licensee in good standing could continue to pay running royalties and, at the same time, bring a declaratory judgment action contesting its obligation to pay on the ground that the licensed patent claim is invalid. ${ }^{23}$ The Court concluded that a paying licensee can bring a declaratory judgment action without first having to breach the license:

We hold that petitioner was not required, insofar as Article III is concerned, to break or terminate its 1997 license agreement before seeking a declaratory judgment in federal court that the underlying patent is invalid, unenforceable, or not infringed. The Court of Appeals erred in affirming the dismissal of this action for lack of subject-matter jurisdiction. ${ }^{24}$

\footnotetext{
* E-mails providing the data are on file with the Stanford Technology Law Review.

22549 U.S. 118 (2007).

${ }^{23}$ Id. at $120-22$

${ }^{24}$ Id. at 137.
} 
T13 Similarly, a defendant-accused-infringer could both take a license and remain an active participant in the litigation, assuming a patentee were willing to offer a license separate from a settlement of the suit. 25

T14 The paying-licensee facts in MedImmune do not directly address the case where a patentee has signaled that it thinks a potential licensee's conduct may be infringing, negotiations about whether a license is even needed may be underway, and the potential licensee brings a declaratory judgment action alleging that the asserted patent is invalid or unenforceable or not infringed. Because, however, the Federal Circuit erred in MedImmune by applying its then-settled two-step analysis for declaratory judgment jurisdiction-did the declaratory judgment plaintiff have a reasonable apprehension of imminent suit from the patentee, and had it engaged in, or taken concrete steps toward, putatively infringing activity? - the MedImmune Court had occasion to impugn that settled Federal Circuit analysis. It stated that the Federal Circuit's approach "contradicts" or "conflicts with" multiple Supreme Court decisions. ${ }^{26}$

The Federal Circuit embraced MedImmune swiftly and completely. A little more than two months after MedImmune, the Federal Circuit applied the Supreme Court's approach to a case involving a putative infringer, SanDisk, who broke off negotiations with a patentee, STMicroelectronics ("ST"), and sued for a declaratory judgment of invalidity. ${ }^{27}$ Patentee ST urged that the ongoing negotiations proved that SanDisk had no reasonable apprehension of an imminent infringement suit from ST. The Federal Circuit repudiated its prior approach: "The Supreme Court's opinion in MedImmune represents a rejection of our reasonable apprehension of suit test." 28 It focused instead on the parties' conflicting claims about ST's asserted right to exclude SanDisk with a patent:

ST communicated to SanDisk that it had made a studied and determined infringement determination and asserted the right to a royalty based on this determination. SanDisk, on the other hand, maintained that it could proceed in its conduct without the payment of royalties to ST. . . SanDisk need not "bet the farm," so to speak, and risk a suit for infringement by cutting off licensing discussions and continuing in the identified activity before seeking a declaration of its legal rights. ${ }^{29}$

The Federal Circuit also highlighted that some assertive step from the patentee is required to trigger declaratory judgment jurisdiction:

In the context of conduct prior to the existence of a license, declaratory judgment jurisdiction generally will not arise merely on the basis that a party learns of the existence of a patent owned by another or even perceives such a patent to pose a risk of infringement, without some affirmative act by the patentee. But Article III jurisdiction may be met where the patentee takes a position that puts the declaratory judgment plaintiff in the position of either pursuing arguably illegal behavior or abandoning that which he claims a right to do. We need not define the outer boundaries .... 30

\footnotetext{
25 See Michael Risch, Patent Challenges and Royalty Inflation, 85 IND. L.J. 1003, 1009-10, 1013-16 (2010).

26 See MedImmune, 549 U.S. at 132 n.11.

${ }^{27}$ SanDisk Corp. v. STMicroelectronics, Inc., 480 F.3d 1372, 1372 (Fed. Cir. 2007).

${ }^{28} I d$. at 1380 (footnote omitted).
}

${ }^{29}$ Id. at 1382 (footnote omitted). To like effect, see Hewlett-Packard Co. v. Acceleron LLC, 587 F.3d 1358, 1364 (Fed. Cir. 2009) ("The facts of this case, when viewed objectively and in totality, show that Acceleron took the affirmative step of twice contacting HP directly, making an implied assertion of its rights under the '021 patent against HP's Blade Server products, and HP disagreed. Therefore, we hold that there is declaratory judgment jurisdiction arising from a 'definite and concrete' dispute between HP and Acceleron, parties having adverse legal interests." (footnote omitted)), and Sony Electronics, Inc. v. Guardian Media Technologies, Ltd., 497 F.3d 1271, 1285 (Fed. Cir. 2007) (upholding declaratory judgment jurisdiction in accused infringer Sony's suit against patentee Guardian: "On the one side, Guardian communicated to Sony its position that certain identified Sony products infringed the '158 and '160 patents. ... On the other side, Sony maintained that the asserted claims of the '158 and '160 patents were invalid in view of certain identified prior art references." (footnote omitted)).

30 SanDisk, 480 F.3d at 1380-81 (emphasis added); see also Prasco, LLC v. Medicis Pharm. Corp., 537 F.3d 1329, 1338 (Fed. Cir. 2008) ("The mere existence of a potentially adverse patent does not cause an injury nor create an imminent risk of an injury; absent action by the patentee, 'a potential competitor . . . is legally free to market its product in the face of an adversely-held patent.” (footnote omitted) (quoting Teva Pharms. USA, Inc. v. Novartis Pharms. Corp., 482 F.3d 1330, 1345 (Fed. Cir. 2007)). 
T16 In short, "once a patentee goes to an alleged infringer and identifies a specific patent and a specific product of the other company, the patentee is immediately at risk of a declaratory judgment action." 31

T17 SanDisk and other post-MedImmune cases enable a significantly wider group of potential infringers to bring their fight to the patentee by declaratory judgment. For example, Judge Bryson, writing separately in SanDisk, surmised that, "if there is any uncertainty" about whether a patentee's communication signals adverse interests,

all the prospective licensee has to do in order to dispel any doubt is to inquire of the patentee whether the patentee believes its activities are within the scope of the patent. If the patentee says "no," it will have made a damaging admission that will make it very hard ever to litigate the issue, and thus will effectively end its licensing efforts. If it says "yes" or equivocates, it will have satisfied the court's test and will have set itself up for a declaratory judgment lawsuit. 32

Importantly, even suits against other, similarly-situated industry players can ground declaratory judgment jurisdiction, at least where a prior notice letter from the patentee links those other players together with the declaratory judgment plaintiff. In Micron Technology, Inc. v. Mosaid Technologies, Inc.,33 patentee Mosaid waged an enforcement campaign against the four leading DRAM chip makersSamsung, Hynix, Infineon, and Micron. In June 2001, Mosaid "sent a warning letter strongly suggesting that Micron should license its technology." ${ }_{4}$ After three more letters over the following year, Mosaid sued Samsung. Multiple suits and settlements later, in July 2005, Mosaid still had not sued Micron. "Press reports," however, "predicted that Micron posed the obvious next target . ..."35 Micron sued Mosaid for a declaratory judgment of noninfringement of fourteen Mosaid patents. Overturning the trial court's dismissal of Micron's suit, the Federal Circuit concluded that, despite Mosaid's more active focus on other purported infringers, Micron had a concrete dispute with Mosaid. ${ }^{36}$ One key for the court, apart from Mosaid's warning letter in 2001, was Mosaid's "recent public statements and annual reports [that] confirm[ed] its intent to continue an aggressive litigation strategy." 37

T19 MedImmune and its aftermath change the patent litigation landscape. A patentee's assertive enforcement step more readily confers the declaratory judgment action option on a significant circle of prospective licensees. Any prospective licensees still in doubt can easily provoke a sufficiently adverse statement. Patentees will thus find it harder to use a complex enforcement strategy that slowly rolls out against different prospective licensees, funding later enforcement actions with earlier successes. At the same time, potential licensees will find it easier to sue at a time and place of their own choosing, or to join ongoing litigation against a similarly situated putative infringer.

Of course, even after MedImmune, the appropriability problem that undercuts definitive patent challenges still remains. Cases such as SanDisk and Micron, however, may well intensify putative infringers' efforts to solve that appropriability problem. And it would be quite troubling if, amid this rising pressure for vigorous challenges, court action were needlessly undercut by structural disincentives: full court involvement in assessing the validity and scope of patent claims is fundamental to the healthy functioning of our patent system. ${ }^{38}$ Indeed, it has been woven into the

${ }^{31}$ Ronald A. Bleeker \& Michael V. O'Shaughnessy, One Year After MedImmune-The Impact on Patent Licensing \& Negotiation, 17 FED. CIR. B.J. 401, 428 (2008).

32 SanDisk, 480 F.3d at 1384-85 (Bryson, J., concurring in the result).

33518 F.3d 897 (Fed. Cir. 2008).

${ }^{34}$ Id. at 899.

35 Id. at 900 .

36 Id. at $901-02$.

${ }^{37} I d$. at 901.

${ }^{38}$ The observation is not a new one: 'The judicial determination of the validity of patents is not a mere 'check' or 'brake' on the accuracy or good judgment of an administrative tribunal, but is itself a fundamental part of the machinery of the patent system." Wm. Redin Woodward, A Reconsideration of the Patent System as a Problem of Administrative Law, 55 HARV. L. REV. 950, 959 (1942). 
basic fabric of the Patent Act since $1790 .{ }^{39}$ Given the ex parte nature of patent prosecution, and the uncertain commercial value of most inventions early in their lives, it could scarcely be any other way. ${ }^{40} \mathrm{~A}$ major stumbling block in the path of a robust research joint venture designed to establish a patent's validity or scope is the conventional understanding of Sherman Act constraints, which makes for weak joint defense agreements. As a result, Jones Knitting is due for thorough reassessment. The best backdrop for that critical reassessment, which I take up in Part III, is a fresh analysis of a durable patent-challenge bloc using the contemporary understanding of such research joint ventures generally.

\section{FIRST PRINCIPLES: ANALYZING A PATENT-CHALLENGE-BLOC AS A RESEARCH JOINT VENTURE}

Litigation involving multiple accused infringers is widespread. Is there a disincentive for any one accused infringer to litigate its defense(s) to judgment? If so, is there a narrowly drawn joint venture that would counteract that disincentive? If so, how should an antitrust court analyze the join venture's legality under $\ 1$ of the Sherman Act? I consider these questions in turn.

\section{A. Court Judgments of Patent Status and Scope are Inappropriablet1}

"[O]nce a U.S. patent has been declared invalid, it is dead and cannot be resuscitated." 42 This is so because of the now-routine approach to collateral estoppel, or issue preclusion, that the Supreme Court ushered into patent law in Blonder-Tongue. 43 To fully appreciate the structural inappropriability of a court judgment of patent invalidity, it is helpful to consider the case in some depth.

In its 1971 decision in Blonder-Tongue, the Court held that an alleged patent infringer can use issue preclusion to foreclose an infringement suit where the patent claim in question had already been declared invalid in an earlier suit. So long as "a patentee has had a full and fair chance to litigate the validity of his patent in an earlier case," the Court held, even an accused infringer who is a stranger to that earlier case can raise "a plea of estoppel" to defend "a charge of infringement of a patent that has once been declared invalid." 44 With this rule in place, an alleged infringer who wins a patent invalidity judgment earns a benefit not only for itself, but for everyone, including those of the winner's competitors who were either practicing the patented technology already or were well positioned to adopt it.

I24 Before Blonder-Tongue, an alleged infringer who successfully challenged the validity of a patent claim had the benefit of that court judgment to itself. In the 1936 case of Triplett v. Lowell, for example, the Court had roundly rejected the contention that a patentee could be estopped from suing on its patent by earlier invalidity judgment. ${ }^{45}$ The Court noted in Triplett that it "ha[d] several times

39 See 35 U.S.C. $\$ 282$ (2006); 35 U.S.C. $\$ 69$ (1925); 1 Rev. Stat. $\$ 4920$ (1875) (Title 60); Act of July 4, 1836, ch. 357, \15, 5 Stat. 117, 123; Act of Feb. 21, 1793, ch. 11, \6,1 Stat. 318, 322; Act of Apr. 10, 1790, ch. 7, \6, 1 Stat. 109, 111.

40 See Lemley \& Shapiro, Probabilistic Patents, supra note 5, at 95 ("The actual scope of a patent right, and even whether the right will withstand litigation at all, are uncertain and contingent questions. This uncertainty is not an accident or mistake. Rather, it is an inherent part of our patent system, an accommodation to the hundreds of thousands of patent applications filed each year, the inability of third parties to participate effectively in determining whether a patent should issue, and the fact that for the vast majority of issued patents, scope and validity are of little or no commercial significance.").

${ }^{41}$ This subsection is adapted from Miller, Better Bounty, supra note 3, at 673-88.

42 Janice M. Mueller, Patent LaW 453 (3d ed. 2009).

43 Blonder-Tongue Labs. v. Univ. of Ill. Found., 402 U.S. 313 (1971).

${ }^{44} \mathrm{Id}$. at 333,350 .

45297 U.S. 638, 642 (1936) ("While the earlier decision may by comity be given great weight in later litigation and thus persuade the court to render a like decree, it is not res adjudicata and may not be pleaded as a defense."). The first Restatement of Judgments was to the same effect, stating that, as a general rule, "a person who is not a party or privy to a party to an action in which a valid judgment other than a judgment in rem is rendered . . . is not bound by or entitled to claim the benefits of an adjudication upon any matter decided in the action." RESTATEMENT (FIRST) OF JUDGMENTS \$ 93(b) (1942). It even illustrated the principle with an example of a second patent infringement defendant unable to plead the first defendant's successful invalidity attack as a defense. Id., cmt. d, illus. 10. Both Triplett and the Restatement simply followed settled practice in this respect. See 2 HENRY C. BLACK, A TREATISE ON THE LAW OF JUDGMENTS: INCLUDING THE DOCTRINE OF RES JUDiCATA \534, at 808 (2d ed. 1902); 
held valid the claims of a patent which had been held invalid by a circuit court of appeals in an earlier suit brought by the same plaintiff against another defendant." ${ }^{46}$ Blonder-Tongue would turn Triplett on its head.

When a court permits defensive nonmutual collateral estoppel in a case that affects a small number of readily identifiable people — such as a contract case concerning a handful of parties, or a tort case from a few crashed cars, each with a passenger or two-the rule eliminates wasteful duplication of litigation effort with only a modest downside risk of distorting litigation incentives. ${ }^{47}$ Perhaps that is why the California Supreme Court case that touched off the rush toward nonmutual collateral estoppel, Bernhard v. Bank of America National Trust \& Savings Ass'n ${ }^{48}$ took no account of the possibility that rejecting the traditional mutuality requirement could diminish each party's incentive to litigate a case to judgment in the first place. Bernhard involved a dispute among a bank, a deceased woman's caretaker, and the four beneficiaries of her estate; at issue was the bank's authority to pay money out of the deceased's account to her caretaker. ${ }^{49}$ In this relatively simple case, involving at most six parties, the California Supreme Court naturally focused on avoiding the waste of duplicative litigation: "it would be unjust to permit one who has had his day in court to reopen identical issues by merely switching adversaries." ${ }^{50}$ Limiting the four beneficiaries of the estate to one attempt to recapture the payout the caretaker received would not undermine their coordination of the effort.

A patent, unlike the typical contract or tort, affects the rights and obligations of everyone in the United States who would practice the technology claimed in it. ${ }^{51}$ Patents are, in this sense, nationwide regulations. ${ }^{52}$ And patent litigation, to the extent it tests the very validity of a given patent grant, affects not only the alleged infringer before the court, but also every other party who is, or may wish to begin, practicing the patented technology. With the rights of so many other independent parties at stake, a nonmutual issue-preclusion rule raises serious questions about who appropriates the bulk of the return on an alleged infringer's investment in a definitive ruling on patent validity. These serious questions, in turn, make each party less likely to make the investment in the first place. And if every alleged infringer pays a royalty to the patentee in the hope that another might take the far more costly step of challenging the patent, the social cost of a wrongly granted patent can far exceed the social cost of an unenforced contract or overlooked tort case.

In any event, by the time the Supreme Court heard Blonder-Tongue, the range of post-Bernhard state and federal cases embracing nonmutual issue-preclusion had grown substantially. ${ }^{33}$ And, just a few years before, a presidential commission had urged that "[a] final federal judicial determination declaring a patent claim invalid [should] be in rem." 54 The commission's intent was to "preclude a

Francis P. Devine, Comment, Blonder-Tongue Bites Back: Collateral Estoppel in Patent Litigation-A New Look, 18 VILL. L. REV. 207, $214(1972)$.

46297 U.S. at 643-44 (listing cases).

47 The duplication is wasteful if, as is usually the case, each court that would adjudicate the case is equally likely to reach the correct result. ROBERT C. CASAD \& Kevin M. Clermont, Res JudicAta 29 (2001); Richard A. POSNER, ECONOMiC ANALYSIS OF LAW $\$ 21.11$, at 635-37 (5th ed. 1998).

48122 P.2d 892 (Cal. 1942); see also Blonder-Tongue, 402 U.S. at 323-26 (discussing Bernhard and its "significant impact" on the adoption of nonmutual preclusion rules in state and federal courts).

49122 P.2d at 893 .

${ }^{50}$ Id. at 895.

51 See Mikohn Gaming Corp. v. Acres Gaming, Inc., 165 F.3d 891, 896 (Fed. Cir. 1998) (noting "the national scope of the patent grant").

52 See John R. Thomas, The Responsibility of the Rulemaker: Comparative Approaches to Patent Administration Reform, 17 BERKELEY TECH. L.J. 727, 741 (2002).

53 Blonder-Tongue, 402 U.S. at 324-27 (collecting and discussing cases and commentaries); A.H. Evans \& W.R. Robins, The Demise of Mutuality in Collateral Estoppel (The Second Round Patent Suit-The Not-So-Instant Replay), 24 OKLA. L. REV. 179, 180 (1971) (noting, just prior to Blonder-Tongue, that "mutuality is essentially dead in all areas of the federal law except patent law"). Indeed, Professor Vestal, a leading authority on preclusion at that time, contrasted Tripletts mutuality rule for patent cases with the nonmutuality rule already common in other areas-what he termed "the normal rules of res judicata/preclusion." ALLAN D. VESTAL, RES JUDICATA / PRECLUSION V-410 (1969) (emphasis added).

54 President’s Comm’n on the Patent Sys., “To Promote the Progress of . . . Useful Arts” in an Age of EXPLODING TECHNOLOGY 38 (1966) (Recommendation XXIII). 
subsequent suit on a patent claim previously held invalid by a Federal court." 55 Perhaps it is less surprising, against this backdrop, that the Court requested on its own initiative that the parties in Blonder-Tongue brief the question whether Triplett should be overruled. ${ }^{56}$

And overrule Triplett it did. The Court made quick work of the patentee's contention that it should not be estopped by an earlier invalidity judgment because "patent litigation [is] so technical and difficult as to present unusual potential for unsound adjudications." ${ }^{57}$ The Court quite correctly focused not on the accuracy of any single patent validity judgment, but on the uniformity of the accuracy level across all patent validity judgments, quipping that "one might ask what reason there is to expect that a second district judge or court of appeals would be able to decide the issue more accurately" than the first. ${ }^{58}$ Moreover, given that the patentee has the flexibility to choose whom, when, and where to sue, "there is no reason to suppose that plaintiff patentees would face either surprise or unusual difficulties in getting all relevant and probative evidence before the court in the first litigation." 59 Neither accuracy nor fairness justified keeping Triplett.

The Blonder-Tongue Court was far more interested in "the acknowledged fact that patent litigation is a very costly process," 60 for both the patentee and the alleged infringer. ${ }^{61}$ It focused on what it viewed as the two chief consequences of patent litigation's high cost. First, successive litigation wasted both parties' money and time, so long as the earlier invalidity judgment was sound. ${ }^{62}$ Second, and "far more significant" to the Court, even an invalid patent continued to have an in terrorem effect against other potential defendants: faced with the choice, "prospective defendants will often decide that paying royalties under a license or other settlement is preferable to the costly burden of challenging the patent," notwithstanding the other alleged infringer's success at invalidating the patent. ${ }^{63}$

930 The Court recoiled at the prospect of firms making royalty payments in tribute to a demonstrably invalid patent. Such payments were "an unjust increment to the alleged infringer's costs" and caused higher consumer prices. ${ }^{64}$ At the same time, the alleged infringer who enjoyed a patent invalidity judgment in its favor could exploit the royalty payments that its weaker rivals were still forced to pay: "Because he is free of royalty payments, the manufacturer with a judgment against the patent may price his products higher than competitive levels absent the invalid patent, yet just below the levels set by those manufacturers who must pay royalties." 65 The Court thus concluded that, in the competition that followed an alleged infringer's successful attack on a patent's validity, another alleged infringer's continuing royalty "payments put him at a competitive disadvantage." ${ }_{66}$ This observation is accurate, but the analysis is incomplete.

931 It is true that, under Triplett, an infringer who succeeds in invalidating a patent may be able to price its patent-dependent good just below the price charged by royalty-paying producers. It is equally true, however, that the patent attacker confronts a fixed cost of bringing the patentdependent good to market that its competitors, who have licensed the patent, do not-namely, the cost of its successful attack on the patent. The premium the patent attacker earns by selling its good at a price just below the price charged by licensees, rather than at marginal variable unit cost, is the

55 Id. at 39. The Blonder-Tongue Court was well aware of the commission's proposal, quoting it and discussing at length the legislative proposals it provoked. See 402 U.S. at 339-42.

56 Blonder-Tongue, 402 U.S. at 313.

${ }^{57}$ Id. at 330.

${ }^{58} \mathrm{Id}$. at $331-32$.

${ }^{59} I d$. at 332.

${ }^{60} \mathrm{Id}$. at 334 .

${ }^{61} \mathrm{Id}$. at 335-36.

${ }^{62} I d$. at 338.

${ }^{63} \mathrm{Id}$.

${ }^{64} I d$. at 346.

${ }^{65} I d$.

${ }^{66} I d$. 
patent attacker's way to recoup that successful attack cost. Indeed, if the patent attacker had no way to charge this premium (e.g., if it shared the patent invalidity judgment with other producers, who thus confronted no royalty cost), one might fairly wonder why the patent attacker would mount the attack in the first place. If it succeeded, its competitors would be free to enter the market and compete away its ability to recoup the litigation costs. The Court described the patent attacker's pricing advantage, and yet failed to see it for what it was, i.e., a vital incentive that encourages a patent attacker to defend against an infringement charge.

The Court viewed Blonder-Tongue as another step in the line of cases designed to "encourage authoritative testing of patent validity." 67 It was mistaken. Blonder-Tongue eliminates a patent attacker's ability to exclude others from appropriating the benefit of its successful patent attack. It turns patent invalidity judgments into public goods. The resulting free rider problem, discouraging patent challenges, is comparable to the one that justifies providing a patent system in the first place. ${ }^{68}$

It is ironic that Blonder-Tongue, a patent infringement case, has generated an incentive problem of the very sort that patent law itself is adapted to solve. Three recent papers offer detailed economic models of the appropriability problem that undercuts patent challenges and the resulting undersupply of patent challenges. Kesan \& Gallo show that "incorrectly issued patents can survive in the marketplace and impose long-term welfare costs on society." ${ }^{69}$ Modeling the choice of a single accused infringer's decision whether to fight or take a license, they identify "high litigation costs" as the primary culprit propping up bad patents. ${ }^{70}$ Farrell \& Merges conclude that, under current law, "a patentee's incentive to defend its patent grossly exceeds an alleged infringer's incentive to challenge it." ${ }^{\prime 11}$ Focusing on "cases where multiple infringers compete with one another (and perhaps with the patentee) in one or more product markets," 72 they point first to the Blonder-Tongue problem: "for instance, if there are five infringers of equal size, each gets only a fifth of the gains from a successful challenge because each is paying only a fifth of the patentee's total royalties," and "the patentee has five times more incentive to prevail in litigation than any one challenger has." 73 They point next to another factor that can further undercut patent challenges: "when multiple infringers compete in a product market, royalties are often passed through, at least in part, to consumers downstream." 74 As a result, a patentee benefits from a small royalty far more than that royalty hurts the competing licensees in the aggregate; the bulk of the harm falls on the consuming public. ${ }^{75}$ Perhaps most importantly, the pass-through phenomenon highlights a powerful strategic weapon in the patentee's arsenal against an accused infringer who wants to stay in the fight: "a license at higher royalties than are offered to [the patentee's] less feisty rivals will substantially lower profits because the increment of royalties cannot be passed on in the same way." 76 Thus the unyielding "firm's profits fall by a large fraction of the increment in royalties, in contrast to the profit effect of uniform royalties among competitors." ${ }^{\prime} 7$ Finally, Farrell \& Shapiro, in the most recent of the three papers, extend Farrell \& Merges by exploring how negotiated royalty rates are likely to vary with a patent's "strength, i.e., the probability $\theta$ that it would be found valid and infringed if tested in court."'78 They conclude that,

\footnotetext{
${ }^{67} \mathrm{Id}$. at 344.

68 The standard economic justification for patent law is that it helps solve a free rider problem that would otherwise lead to the undersupply of new inventions. See, e.g., Mark A. Lemley, Ex Ante versus Ex Post Justifications for Intellectual Property, 71 U. CHI. L. REV. 129, 129 (2004) [hereinafter Lemley, Ex Ante] (summarizing the standard model); Miller, Better Bounty, supra note 3, at 680-83

${ }^{69}$ Kesan \& Gallo, Why "Bad" Patents Survive, supra note 14, at 76.

${ }^{70} I d$. at $77-86$.

${ }^{71}$ Farrell \& Merges, Incentives to Challenge, supra note 14, at 951.

72 Id. at 952 .

${ }_{73} I d$.

${ }^{74}$ Id. at 953.

${ }^{75}$ Id. at $953-54,969-70$.

${ }^{76} I d$. at 956 (emphasis added).

${ }_{77} \mathrm{Id}$. at 956 n.37.

${ }^{78}$ Farrell \& Shapiro, How Strong Are Weak Patents?, supra note 14, at 1348.
} (same). 
"when downstream firms use the patented technology in competing against each other or against the patent holder, ... downstream firms will accept surprisingly large per-unit royalties." 79 Specifically, the negotiated royalty "is a large multiple of" the "expected royalty that would result if validity were determined prior to licensing," and—-most disturbing—-the effect holds "especially for weak (small $\theta$ ) patents." 80

These economic models help confirm that current law is structurally tilted against an efficient supply of definitive patent challenges. The current statutory quasi-bounty tailored specifically to encourage generic drug makers, comprising a six-month semi-exclusivity period for the first successful patent challenger in line, ${ }^{81}$ is unlikely to spur a more general statutory fix. The question naturally arises, then, whether private agreements might overcome this appropriability problem.

\section{B. Credibly Sharing Costs Solves the Appropriability Problem}

A patent's status and scope-is it invalid? does this or that item infringe?-are bits of information. One establishes this information in litigation..$^{82}$ The problem that Blonder-Tongue creates, especially for a weak patent covering a technology that many firms use as an input in a competitive downstream market, is a disconnect between the cost of testing the patent's legitimacy (which is relatively large) and the benefit realized by one of those many firms if the patent is invalidated (which is relatively small). ${ }^{83}$ The solution is to close that gap: "To have the incentive to undertake research and development, a firm must be able to appropriate returns sufficient to make the investment worthwhile." 84 There is little that can be done to close the gap from the benefit side. A judgment in a patent case cannot be kept secret. Absent a cash bounty paid only to the attacker, the only benefit unique to the attacker is a lead-time advantage over its rivals in making full use of the disputed technology, assuming those rivals have not been practicing the claimed invention. The gain from this lead-time advantage is likely trivial compared to the great expense of patent litigation or the sacrificed benefit of taking an early license at a discount, especially in a case where the patent had a substantial part of its term remaining at the time of the challenge. The gap between cost and benefit must therefore be closed, if at all, from the cost side. The natural means to do so is by an agreement among the potential beneficiaries of a successful challenge to share its costs, in proportion to each party's liability exposure or a convenient proxy for it (e.g. market share). ${ }^{85}$

A research joint venture among the firms that use, or want to use, the patented technology can attract members, and thereby succeed, only if the commitment each member makes to the venture is credible, i.e., binding through the end of the litigation that comprises the venture's research project. Achieving a credible commitment requires terms designed to protect the venture from patentee tactics designed to frustrate the venture. This is easiest to see if we start with a hypothetical research joint venture that requires each member to help fund the patent challenge while the member is an active or potential defendant in the challenge. If the patentee were to settle with a defendant or presettle, as it were, by licensing a potential defendant, the patentee could end that party's contribution to the fund. Picking off well-selected targets in series, the patentee could quickly cripple the fund.

${ }^{79} I d$. at 1349.

${ }^{80}$ Id.; see also Lemley \& Shapiro, Probabilistic Patents, supra note 5, at 89 ("[T] he royalties commanded by the owner of a probabilistic patent can easily be disproportionate to the strength of the patent and are highest when a single licensee's profits are very sensitive to its own costs but not sensitive to the level of industry-wide costs.").

${ }^{81}$ Miller, Better Bounty, supra note 3, at 722-28.

82 See supra notes 38-40 and accompanying text.

83 See supra note 5.

84 Richard Levin et al., Appropriating the Returns from Industrial Research and Development, 3 BROOKINGS PAPERS ON ECON. ACTIVITY 783, 783 (1987).

85 See Brodley, supra note 19, at 1570-71 ("Research is by nature a high-risk activity. Yet, except when protected by patents or obscured by secrecy, the fruits of successful research can be appropriated by other firms with little, if any, cost outlay. . . Joint research tends to solve [such] problems. The research risk to the individual firm is reduced because it is shared. In addition, joint research increases the return on research investment at the firm level, because more of those who profit from the research share in its costs."). 
The venture agreement should thus include a further requirement that each member contribute its share to the litigation fund without regard to whether it later settles with or takes a license from the patentee.

This revised agreement is stronger, but it is still too weak. Take the revised joint venture agreement as the new baseline: Each member contributes to the research fund until the litigation fully concludes, whether or not it settles with or takes a license from the patentee. How, in this context, can the patentee pit members against each other in an effort to cripple the venture? One possible expedient is to offer a graduated discount schedule for royalties that rewards earlier exit from the litigation - a "hardball" strategy patentees can use to great effect generally, as Farrell \& Merges have explained. ${ }^{86}$ Such graduated discounts could set off a race among the members not to be the lone remaining defendant leading a now greatly weakened venture. ${ }^{87}$ That race to the exit, if it starts, makes it more likely the asserted patent will escape a robust court test of its validity or scope. The venture agreement should thus include a further requirement that each member decline any royalty discounts compared to later licensees, or-what amounts to the same thing-neutralize any time-based discount by reimbursing late licensees for what will be their nominally higher royalties, from a fund supplied by early licensees with nominally lower royalties. ${ }^{88}$

This latter revision-guarding against time-based graduated discounts-raises an additional, more general, concern. Patentees blocked from licensing someone out of the venture and from using discounted royalties to fray the venture may try to approximate the royalty discount with some other license term that favors earlier licensing with a lower compliance cost. The best guard against such tactical licensing is the licensee's full disclosure of all license terms to any other venture member who wants to know the information to verify that it is no worse off than an earlier-licensing co-venturer. The venture agreement should thus include, at a minimum, a further requirement that each member disclose to all other members the full terms of any license it takes, or settlement it makes, with the patentee.

I39 To summarize: A research joint venture formed to test a patent's validity and scope can solve the appropriability problem that undercuts patent challenges if the venture's membership agreement establishes that venture members are credibly committed to the venture's goal-establishing the information contained in a final, unappealable court judgment on the patent's status and scope. An agreement simply to contribute to the litigation fund while one is an actual or potential defendant is inadequate. A further agreement to contribute without regard to license or settlement, although necessary, is not sufficient; without more, the patentee would still have tactical means to undermine the venture. A further agreement to disclose all license or settlement terms is also necessary, as is a further agreement to decline any royalty discounts pegged to the date one takes a license.

T40 A research joint venture that shares information and costs according to the terms just stated is well tailored to solve the appropriability problem that Blonder-Tongue creates. Does it comply, however, with the Sherman Act's prohibition on unreasonable restraints of trade among

86 "Patentees can also charge differential royalties in a way that penalizes holdout firms who do not settle early. This hardball behavior by the patentee . . . further weakens the infringer's incentive to challenge in the first place rather than quietly pay up." Farrell \& Merges, Incentives to Challenge, supra note 14, at 954-55 (footnote omitted); see also id. at 956 ("Litigating and losing may be much worse for the infringer than paying the royalty... [A] license at higher royalties than are offered to its less feisty rivals will substantially lower profits because the increment of royalties cannot be passed on in the same way.").

${ }^{87}$ The venture won't be weakened financially; each member will continue to contribute to the litigation fund in proportion to its exposure or market share. But a research venture in which most members grudgingly write contribution checks and otherwise seek to minimize their burdens is obviously weaker than one in which most or all members fully participate in reaching the venture's goal.

${ }^{88}$ It is not clear to me that any particular mechanism for deflecting a patentee discount campaign—a sort of inverse-MFN clause* included at the licensee's request, or a reimbursement fund among licensees established as needed-risks a greater avoidable harm to competition in the downstream market than the other mechanism(s). If it becomes clear that one mechanism risks less harm to downstream competition than the other(s), ventures should be limited to using the less risky mechanism.

* A most-favored-nation, or MFN, clause is one "providing that each [signatory] will treat the other as well as it treats any other nation that is given preferential treatment." BLACK'S LAW DICTIONARY 1105 (9th ed. 2009). In other words, the promisor promises not to treat other promisees better than it treats the target promisee. In the inverse-MFN suggested here, the promisor promises not to treat the target promisee better than it treats other promisees. 
competitors? The answer turns on whether, on balance, the venture promotes competition more than it inhibits it.

\section{A Durable Patent-Defense Joint Venture Is Procompetitive}

The research joint venture under consideration here is structured to fund a definitive challenge to an asserted patent. The information resulting from that challenge is publicly known, and, after the venture's conclusion, each former member is free to use the information embodied in the court judgment to its greatest competitive advantage. As a result, our analysis is not principally concerned with competition in the downstream market for which access to the patented invention is an input. Except in the unusual case where the royalty cost of the license approaches the final cost of the downstream item that licensees sell, and the royalty thus could serve as a mechanism for colluding on price in the downstream market, the joint venture agreement does not affect the downstream competitive process itself. Rather, our analysis of the joint venture's competitive impact focuses on the net effects of a collaboration among competitors to establish information of great benefit to all of them but too costly for any one of them.

T42 Before analyzing the patent-defense-bloc venture's net effects, it is important to emphasize what the venture is not. It is not a price-fixing agreement. When alleged infringers agree outright not to license a patent at all at any price, or not to license it except at a predetermined royalty of $\$ X$, they engage in oligopsonistic price-fixing that does nothing to generate more information and serves only to artificially depress the price of access to the patented technology. Such an agreement should, and does, trigger antitrust liability per se. ${ }^{89}$ The patent-defense joint venture is also not an agreement to bargain jointly as a unit for a settlement or license. An agreement to bargain jointly for a license could raise concerns, even without fixing the price in advance, because " $[\mathrm{b}] \mathrm{y}$ negotiating jointly, the members of an industry may be able to obtain a license for a lower price than if they bargained individually." 90 Because "independent centers of decisionmaking" are what "competition assumes and demands," 91 the patent-defense joint venture leaves every member free to bargain individually with the patentee based on the information the venture establishes.

943 Is this venture procompetitive? "Joint ventures are an important and distinct category for antitrust analysis because of their potential to bring about an efficiency-enhancing integration of economic activity." 92 The patent-defense bloc is a research joint venture designed to establish information that is valuable to venture members, and that is unlikely to be discovered absent the venture. Contemporary antitrust analysis indicates that such a joint venture is fit for rule-of-reason analysis and is likely procompetitive. For example, the current edition of Antitrust Law Developments observes the following:

Research joint ventures often provide procompetitive benefits, such as sharing the substantial economic risks involved in $\mathrm{R} \& \mathrm{D} \ldots$. . and overcoming the free-rider disincentive to invest in $\mathrm{R} \& \mathrm{D}$ by including likely $\mathrm{R} \& \mathrm{D}$ end-users in undertaking the research efforts and sharing the costs. For this reason, joint research ventures are typically analyzed under the rule of reason, and the courts have long viewed such agreements more favorably than many

89 See, e.g., Sony Elecs., Inc. v. Soundview Techs., Inc., 157 F. Supp. 2d 180 (D. Conn. 2001) (discussing antitrust liability for alleged agreement among technology users to pay no more than a $\$ 0.05 /$ unit royalty under a patent). Generally speaking, "buyer cartels, the object of which is to force the prices that suppliers charge the members of the cartel below the competitive level, are illegal per se. Just as a sellers' cartel enables the charging of monopoly prices, a buyers' cartel enables the charging of monopsony prices; and monopoly and monopsony are symmetrical distortions of competition from an economic standpoint." Vogel v. Am. Soc'y of Appraisers, 744 F.2d 598, 601 (7th Cir. 1984) (Posner, J.) (citations omitted); see also 12 AREEDA \& HovENKAMP, supra note 19, at 92010 ("Properly defined naked price fixing by buyers raises the same issues and poses the same dangers as price fixing by sellers. ... [B] [uyers' cartels . . are readily condemned under the per se rule."), $\uparrow 2011 \mathrm{~b}$ (discussing economic consequences of buyer price fixing).

${ }^{90}$ Mark A. Lemley, Intellectual Property Rights and Standard-Setting Organizations, 90 CAL. L. REV. 1889, 1940 (2002).

${ }^{91}$ Copperweld Corp. v. Independence Tube Corp., 467 U.S. 752, 769 (1984).

92 Werden, Joint Ventures, supra note 19, at 702. 
other types of joint ventures..$^{93}$

944 Indeed, just this term, the Supreme Court emphasized that "[w]hen 'restraints on competition are essential if the product is to be available at all,' per se rules of illegality are inapplicable, and instead the restraint must be judged according to the flexible Rule of Reason." "94 Moreover, "[i]n such instances, the agreement is likely to survive the Rule of Reason." 95

945 The rule of reason requires a highly fact-specific assessment of whether an agreement, on balance, promotes competition more than it suppresses it in a context in which the agreement is reasonably necessary. ${ }^{96}$ Put another way, in such a case, "the finder of fact must decide whether the questioned practice imposes an unreasonable restraint on competition, taking into account a variety of factors, including specific information about the relevant business, its condition before and after the restraint was imposed, and the restraint's history, nature, and effect." 97 An analysis of a whole class of joint defense agreements, such as can be presented here, thus cannot help but be provisional. At the same time, a hypothetical joint venture scenario should bring the primary effects on competition into view.

946 Assume that a patentee has sued, or threatened to sue, the six largest firms that compete to sell a particular good, alleging that the patent covers the good. Together, these firms fill about $90 \%$ of the demand for the offering that the patent purportedly covers. The technology described in the patent is not currently used in any other offering, so these six firms constitute the lion's share of (i.e., have market power in) the market for licenses to the asserted patent. ${ }^{98}$ The firms form a bloc, hiring a single law firm to handle their joint defense. Each firm commits to share relevant information about prior art in the field and to pay into the joint defense fund a share, based on its market share, of the cost of defending against the infringement allegations. Each agrees to pay through to a final and unappealable judgment on all colorable validity, enforceability, and scope issues. The agreement expressly provides that (1) a member's obligation to pay is not affected by a subsequent decision to settle with the patentee or license the patent, (2) all the terms of any settlement or license that is reached must be disclosed to other members, and (3) a member will not accept a time-based royalty discount from the patentee. Each of the six firms is free to settle with the patentee on whatever other terms it likes, subject to these venture obligations. Finally, it is clear that the firms have no agreements regarding the terms on which they presently compete, or will later compete, in the downstream market for the allegedly infringing good. After the litigation ends, they will continue to make their decisions about this downstream good competitively, not collusively.

Have the six bloc members promoted competition more than they have restrained it? Like any joint defense agreement, the one contemplated here generates substantial efficiencies by reducing legal costs; one suit costs less than six. More importantly, however, the agreement generates efficiencies because it counteracts the free rider problem that would otherwise prevent the venture participants from establishing valuable information about the asserted patent's status and scopeinformation that only a robust patent challenge can generate. And definitive patent challenges generate efficiencies no matter who wins them.

T48 If the accused infringers mount a definitive challenge to the patent and win, they enhance competition by establishing that the patentee has no right to demand a tribute for access to the

931 AnTitrust Law DevelopmenTs, supra note 19, at 445-46; see also Werden, Joint Ventures, supra note 9, at 713 (“Any genuine economic integration that plausibly could confer nontrivial social benefits suffices to take a joint venture outside the purview of the per se rules applied to cartel activity.") (footnote omitted).

${ }^{94}$ Am. Needle, Inc. v. Nat'l Football League, 130 S. Ct. 2201, 2216 (2010) (quoting Nat'l Collegiate Athletic Ass'n v. Board of Regents of Univ. of Okla., 468 U.S. 85, 101 (1984)).

${ }_{95} \mathrm{Id}$.

96 See generally Leegin Creative Leather Prods. v. PSKS, Inc., 551 U.S. 877, 885-87 (2007) (adopting rule-of-reason analysis for minimum resale price maintenance agreements); 1 ANTITRUST LAW DEVELOPMENTS, supra note 9, at 46-49, 56-57.

${ }^{97}$ State Oil Co. v. Khan, 522 U.S. 3, 10 (1997). For the classic formulation, see Board of Trade of City of Chicago v. United States, 246 U.S. 231, 238 (1918) (Brandeis, J.).

98 The most likely patent-challenge-bloc to form is one that includes firms that, taken together, have market power for licenses to the patent. This is because firms with larger patent liability exposure have a greater incentive to challenge the patent. 
technology. Consumers may benefit from lower prices in the downstream market, given the absence of any future royalty costs that would be passed on to them. Quite apart from any reduction in consumer prices, however, eliminating the improvident patent makes the market for improvements to the technology more competitive. This is an important dynamic efficiency. Having invalidated the patent, improvers no longer need to worry about splitting future gains with, or clearing a block by, a dominant pioneer; they are less "vulnerable to bargaining breakdown, strategic behavior, or valuation error." 99 Admittedly, even as to a valid patent, "the notion of a patent's social costs should include its potential to reduce competition in the market for improvements to the patented technology." 100 But with respect to an invalid patent, there is no serious counterweight to the benefit of competing improvers: although "a rivalrous structure surely has its inefficiencies," it "tend[s] to generate rapid technical progress and seems a much better social bet than a regime where only one or a few organizations control the development of any given technology." 101 In this sense, it would be a mistake to dismiss the change brought about by a successful patent challenge as a mere wealth transfer from patentee to licensees; so long as there are multiple licensees, needless royalties to an improvident patent are not only wealth transfers, they are innovation-hampering wealth concentrators. ${ }^{102}$ We are better off leaving those resources spread among multiple competing innovators, to underwrite the inventions they make to better compete with each other. Finally, the other social costs inflicted by an invalid patent are also avoided. ${ }^{103}$

T49 If the accused infringers mount a definitive challenge to the patent and lose, they enhance efficiency by establishing more clearly the patent's validity and scope. These now-clarified patent rights can be licensed, or asserted, with lower transaction costs going forward, even as to improvers. In addition, the clarified boundaries lower the cost of inventing around the patent to create noninfringing alternative technologies. These efficiencies are largest when the patent is challenged early in its term, but they exist even for older patent rights.

So much for the venture's upside. On the downside, the agreement unquestionably restrains competition somewhat, in the short term, in the market for licenses to the challenged patent. The bloc members' continuing obligation to pay into the defense fund, without regard to settlements with or licenses from the patentee, doubtless drives down the price that an accused infringer is willing to pay for a license to the patent. It also likely drives up the price the patentee will demand for a license, inasmuch as the patentee knows that reaching settlement with one of the six firms does not reduce the funds available to the remaining five firms in their fight to avoid infringement liability. Lowering the alleged infringer's maximum acceptable settlement price and raising the patentee's minimum acceptable settlement price surely makes it harder for these parties to find a mutually agreeable settlement or license. The disclosure and inverse-MFN provisions further restrain competition in the license market, by depriving the patentee of the means to pit venture members against one another in a race to license out of the litigation. The venture agreement does not, however, eliminate competition

99 Mark A. Lemley, Property, Intellectual Property, and Free Riding, 83 TEx. L. REV. 1031, 1060 (2005); see also Lemley, Ex Ante, supra note 68, at 137 ("Creators are often terrible managers. They frequently misunderstand the significance of their own invention and the uses to which it can be put.").

100 Robert P. Merges \& Richard R. Nelson, On the Complex Economics of Patent Scope, 90 Colum. L. REV. 839, 843 (1990).

101 Id. at 908; see also id. at 884-97 (reviewing case studies from the history of cumulative technologies such as electrical lighting, airplanes, automobiles, radio, semiconductors, and computers); Lemley, Ex Ante, supra note 68, at 135 ("The argument that a single company is better positioned than the market to make efficient use of an idea should strike us as jarringly counterintuitive in a market economy. Our normal supposition is that the invisible hand of the market will work by permitting different companies to compete with each other. It is competition, not the skill or incentives of any given firm, that drives the market to efficiency.").

102 As Professor Wu recently observed, "a growing body of scholarship ... suggests that the most important economic effects of intellectual property may not be effects on price, but rather on industry structure." Tim Wu, Intellectual Property, Innovation, and Decentralized Decisions, 92 VA. L. REV. 123, 123 (2006). Moreover, "[i]n general, the economic literature strongly favors decentralized decision structures in economic systems, based on the observation that free-market economies perform better than planned, centralized economies." Id. at 126.

103 These costs include costs that third parties incur to use noninfringing alternative technologies; unrealized gains from beneficial activities that third parties avoid for fear of infringement liability, including activities that would have led to other innovations; and unrealized gains from beneficial activities that patentees would have undertaken were they not distracted by rentseeking efforts to obtain dubious patents and enforce those patents against others. See Miller, Better Bounty, supra note 3, at 690. 
among the alleged infringers in the license market during the litigation. And the three provisions that enable credible commitments from members to the joint venture's goal are no more restrictive than needed to actually make the venture a reality - that is, they are valid ancillary restraints. ${ }^{104}$ Nor does the venture agreement affect competition among the alleged infringers after the conclusion of the patent litigation. Finally, the agreement does not restrain competition at all in the market for the allegedly infringing good.

951 On balance, the gains from more certainly establishing whether the patentee has any right to control access to the underlying technology exceed any losses from the short-term downward pressure on the patentee's ability to obtain royalty revenue while the litigation is pending. Under the rule-of-reason analysis appropriate to research joint ventures, then, a patent-defense-bloc agreement strong enough to withstand a patentee's counteroffensive passes muster under the Sherman Act. Although some outmoded antitrust authorities make such a defense bloc appear problematic, the problems are illusory.

\section{OLD BLUNDERS: MISTAKING A PATENT-CHALLENGE-BLOC FOR AN UNLAWFUL GROUP BOYCOT'T}

The norm in contemporary patent litigation is plural accused infringers. Current doctrine tilts structurally against definitive patent challenges. And the contemporary antitrust analysis appropriate to research joint ventures indicates that a patent-challenge-bloc with the terms described in Part II is procompetitive. One last question remains: Is the Jones Knitting line of cases-which began more than five years before Blonder-Tongue created the appropriability problem that undercuts patent challenges - a better analytical fit for assessing the competitive consequences of an adequately binding joint defense agreement? It is not, because it proceeds from the hidden, and faulty, premise that licensing a patent is not materially different from buying a bushel of sugar beets or a barrel of milk. Sugar beet buyers do not need a research venture to determine whether the purported beets actually exist, or whether the seller has good title. Prospective patent licensees, however, do.

I53 Begin with the conventional view of Jones Knitting and its progeny. On the one hand, multiple firms who are sued for patent infringement (or threatened with suit) can mount a joint defense, spreading costs among pending defendants and sharing information, without fear of antitrust liability. ${ }^{105}$ On the other hand, by analogy to group boycott cases involving commodities or other settled property rights (such as sugar beets for refiners, ${ }^{106}$ or milk for cheesemakers ${ }^{107}$ ), a joint defense agreement triggers antitrust liability if it extends beyond basic cost or information sharing to

104 'A restraint is ancillary if it 'contributes to' or is 'subordinate and collateral to' the efficiency-enhancing purposes of a joint venture." 1 ANTITRUST LAW DEVELOPMENTS, supra note 9, at 466. For example, "[a] collateral restraint may prevent nonparticipants from appropriating joint venture benefits for which they have not shared the costs," Werden, Joint Ventures, supra note 19 , at 707 , which is what the pay-even-after-settlement provision does. Similarly, "[a] collateral restraint may prevent a participant in a joint venture from appropriating an undue share of the venture's benefits," id., which is what the inverse-MFN provision does. These agreements are necessary to the patent-defense joint venture's successful formation, and thereby promote the same efficiencies as the venture itself. See Polk Bros., Inc. v. Forest City Enters., 776 F.2d 185, 189 (7th Cir. 1985) ("A restraint is ancillary when it may contribute to the success of a cooperative venture that promises greater productivity and output. If the restraint, viewed at the time it was adopted, may promote the success of this more extensive cooperation, then the court must scrutinize things carefully under the Rule of Reason.") (Easterbrook, J.) (citations omitted).

105 See Lemelson v. Bendix Corp., 621 F. Supp. 1122, 1133-34 (D. Del. 1985) (granting summary judgment of no liability on a Sherman Act $\ 1$ claim against members of a joint patent-infringement defense group on the ground that evidence showed merely that the parties agreed to share litigation costs and settlement information, and used the same lawyer to handle the case and to conduct some of the settlement talks); Gould v. Control Laser Corp., 462 F. Supp. 685, 692-93 (M.D. Fla. 1978) (granting summary judgment of no liability on a Sherman Act $\int 1$ claim against members of a joint patent-infringement defense group, on the ground that the patentee failed to produce any evidence that there was "more than an agreement to share the costs of litigating the validity of [the] patent," and antitrust liability requires proof of "the existence of a restraint on the freedom of the defense group members to purchase a license"), aff'd, 650 F.2d 617, 620-22 (5th Cir. 1981) (Unit B) (affirming the grant of summary judgment to the extent it denied injunctive relief).

106 Mandeville Island Farms, Inc. v. American Crystal Sugar Co., 334 U.S. 219 (1948).

${ }^{107}$ Knevelbaard Dairies v. Kraft Foods, Inc., 232 F.3d 979 (9th Cir. 2000). 
limit, even modestly, the agreement members' individual freedom to settle with the patentee. ${ }^{108}$ The key case remains Jones Knitting. ${ }^{109}$

In Jones Knitting, patentee Morgan asserted a newly issued patent on knitted thermal fabric against the thermal underwear industry. ${ }^{110}$ In response, twelve producers met to form a joint defense fund and hire patent counsel to investigate the validity of Morgan's new patent. ${ }^{111}$ The only component of their agreement that Morgan later challenged as an antitrust violation was as follows: "in the event Morgan approached any member of the group, that member would do nothing until after he had notified the others in the group." 112 The joint defense agreement did not include a maximum acceptable license price term or any other term that coordinated or limited a member's individual, independent authority to settle out of the case or license the patent. After receiving its patent counsel's opinion that the Morgan patent was invalid, the joint defense group filed a declaratory judgment action seeking to void the patent. ${ }^{113}$

I55 On the patent infringement count, the district court struck down the asserted claims of Morgan's patent on a number of different grounds. ${ }^{114}$ On Morgan's antitrust count, the district court held that the joint defense agreement violated Sherman Act $\int 1$. The alleged infringers had defended the agreement on the ground that it was reasonable to allow joint patent challengers to "keep one another advised of individual settlement negotiations." 115 Morgan argued, however, that it was unlawful for the group to "act collectively to relinquish or inbibit their individual freedom in" refusing to deal with the patentee. ${ }^{116}$ In other words, according to Morgan, an agreement that did no more than diminish a defendant's practical inclination to settle, even if it did not preclude that defendant's formally independent settlement authority, was an unlawful group boycott. The court agreed, striking down the alleged infringers' joint defense agreement as a per se unlawful "group boycott."117 According to Judge Wright, the alleged infringers

agreed not to negotiate with Morgan without first communicating with the others. Their individual freedom was impeded, however slightly, by the promise to communicate before

108 See, e.g., Sony Elecs., Inc. v. Soundview Techs., Inc., 157 F. Supp. 2d 180, 187 (D. Conn. 2001) (denying alleged infringers' motion to dismiss an antitrust claim, on the ground that patentee "Soundview has alleged that the television manufacturers agreed on a license price [of $\$ 0.05$ per television V-Chip], and that they engaged in a joint boycott and concerted refusal to deal"); Lemelson v. Bendix Corp., 104 F.R.D. 13, 17 n.7 (D. Del. 1984) ("The crucial inquiry is whether plaintiff has produced evidence of an agreement among defendants which had the effect of restraining individual freedom of action and preventing settlement negotiations or licensing except upon terms acceptable to the group."); Gould, 462 F. Supp. at 691 (denying alleged infringer's motion to dismiss an antitrust claim, on the ground that patentee Gould "alleged that each of the participants in the patent defense group agreed not to take a license from Gould except upon terms approved by the group as a whole," which, if proved true, "unquestionably restrained the freedom of each group member to act as an individual producer in the laser market"); see also Lemley, supra note 90, at 1942 ("Defendants with common interests who act jointly must retain independent decision-making authority. If they act in concert in deciding not just how to litigate the case, but whether to settle and on what grounds, they have crossed the line into a conspiracy to restrain trade.").

${ }^{109}$ Jones Knitting Corp. v. Morgan, 244 F. Supp. 235 (E.D. Pa. 1965) (Caleb Wright, J.), aff'd in relevant part, 361 F.2d 451 (3d Cir. 1966).

Judge Wright also decided Lemelson v. Bendix Corp., another core case on this topic. See Lemelson, 621 F. Supp. at 1125. According to his Federal Judicial Center biography, Judge Wright was a U.S. District Court Judge for the District of Delaware, where Lemelson was heard, not the Eastern District of Pennsylvania, where Jones Knitting was heard. See Biography of Judge Wright, Federal Judicial Center, http:/ / www.fjc.gov/servlet/nGetInfo?jid=2657\&cid=46\&ctype=dc\&instate=de (last visited Feb. 9, 2011). The official report in Jones Knitting does not indicate that Judge Wright was sitting by designation in the case, although that appears to have happened.

110244 F. Supp. at 236. He sent out notice letters three days after the patent issued. Id.

${ }^{111} \mathrm{Id}$.

112 Id. Later in the opinion, Judge Wright summarized the evidence of the agreement as follows: "It seems plain that the participants at the July 16 meeting did not contemplate an across the board refusal to deal with Morgan with regard to licenses but only an undertaking to notify the other members of the group should they decide individually to negotiate with Morgan." Id. at 238. Morgan did "not claim that formation of a group to take action against a patent and prorate the expense of litigation is unlawful." Id. at 237. Indeed, the patentee was "emphatic on this point." Id. at 237 n.8.

113 Id. at 236-37.

114244 F. Supp. 219, 222-34 (E.D. Pa. 1964). The Third Circuit would later overturn this result, reinstating the patent claims. 361 F.2d at $452-59$.

115244 F. Supp. at 238.

${ }^{116} I d$. at 237-38 (emphasis added).

117 Id. at 238 . 
acting. It does not matter that each plaintiff considered himself to be free to negotiate with Morgan. Each had, in fact, circumscribed his freedom by promising not to take a license until he had informed the others, should he contact Morgan or be contacted by Morgan. ${ }^{118}$

T56 Remarkably, he concluded that the agreement was unlawful per se "whether or not any individual considered his freedom of action impeded." 119 All that mattered was that, at least formally, "that freedom was in fact impeded." 120 Judge Wright linked this formalistic approach back to the per se nature of the violation: "where the per se rules are in effect, a given activity is condemned out of hand and a court may not sift the reasonableness of the restraint, however minor, or look to justification for it."121 In short, for Judge Wright, a per se prohibition made for a hair trigger.

957 The Jones Knitting court relied on two Supreme Court cases-Klor's, Inc. v. Broadway-Hale Stores, Inc., ${ }^{122}$ and Radiant Burners, Inc. v. Peoples Gas Light \& Coke Co. ${ }^{123}$-for the proposition that "[g]roup boycotts are per se violations of the Sherman Act." 124 It did not, however, engage in any factual comparison of the alleged infringers' joint-defense agreement with the group boycotts condemned in Klor's and Radiant Burner. Nor did the Jones Knitting court take any account of the probabilistic nature of patents, a particularly curious omission in the context of its earlier decision to invalidate the asserted patent claims on multiple grounds.

I58 As a factual matter, neither Klor's nor Radiant Burner supports the district court's decision in Jones Knitting. Neither case concerned probabilistic patent rights, or any other probabilistic property rights. Instead, both cases condemned group decisions that were designed to harm an outsider against whom group members competed in the targeted product market, and thus harm competition itself in that product market. In Klor's, a department store chain allegedly set up an agreement with appliance manufacturers and distributors not to sell inventory to a local appliance store against which the department store competed in a particular town. ${ }^{125}$ The Supreme Court, overturning lower court decisions that dismissed the local store's antitrust complaint for failure to state a claim, held that the local store had alleged a per se antitrust violation: one retailer had used its power over manufacturers to combine with them against a competing retailer "and drive[] it out of business as a dealer in the [manufacturers'] products." 126 In Radiant Burner, a trade association comprised of, among others, several burner makers allegedly agreed to deny its seal of approval to Radiant Burner's ceramic gas burner product. ${ }^{127}$ Because utilities would not sell gas into a home unless it had a burner with the trade association's seal of approval, Radiant Burner could not sell its product in competition with the association's members. ${ }^{128}$ Once again, the lower court dismissed the antitrust complaint for failure to state a claim. ${ }^{129}$ And, once again, the Supreme Court reversed, analogizing the case to Klor's and holding that Radiant Burner had alleged a per se unlawful attack on the competitive process. ${ }^{130}$

I59 The alleged infringers in Jones Knitting, in contrast to the department store in Klor's and the trade association members in Radiant Burner, did not make an agreement targeted, in design or effect, at an outsider's ability to compete against the insiders in their product market. No knitwear maker was prevented from selling its own products, or barred from obtaining inventory for resale, by the joint defense agreement. The alleged infringers' agreement simply aimed to keep members on board for

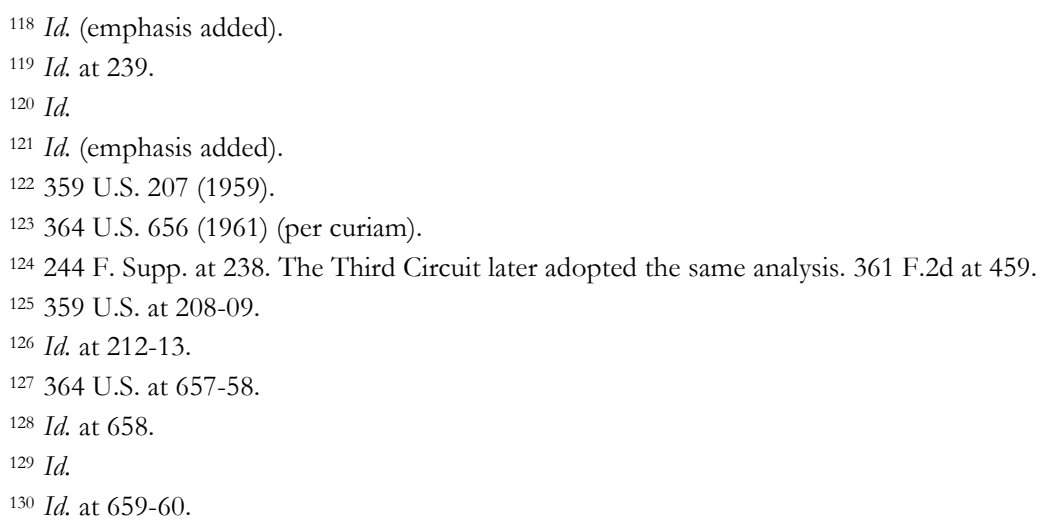


the duration of the infringement litigation. One might find reason to reject this joint defense agreement as anticompetitive, but the Court's condemnation of the agreements in Klor's and Radiant Burner is no basis for doing so. Nor would Jones Knitting's analysis fare any better were one to attempt to root it in more superficially pertinent buyer's-cartel precedents, such as Swift \& Co. v. United States, 131 Mandeville Island Farms, Inc. v. American Crystal Sugar Co., ${ }^{132}$ or Radovich v. National Football League. 133 In all these cases, the buyers were colluding to set the price of the item in question, not pooling resources to research whether the item actually existed. Although the market distortion was monopsony rather than monopoly, ${ }^{134}$ the basic mechanism-fixing prices-was, and remains, unlawful per se. ${ }^{135}$

Two more cases complete the Jones Knitting line: Gould v. Control Laser Corp. ${ }^{136}$ and Lemelson v. Bendix Corp. ${ }^{137}$ Both occurred after Blonder-Tongue, but neither mentioned the appropriability problem that case created for accused infringers. Neither mentioned the probabilistic nature of patent rights. Both did, at least, acknowledge that, in the years after Jones Knitting, appellate courts—and, ultimately, the Supreme Court-had greatly circumscribed the use of per se illegality and that a rule-of-reason analysis was appropriate for joint defense agreements. ${ }^{138}$ But both also perpetuated the basic groupboycott frame of Jones Knitting. 139 Indeed, in Lemelson, Judge Wright put the case on the same hair trigger: "a prima facie case of conspiracy . . . requires evidence from which it is reasonable to infer some restriction on the freedom of the defendants to negotiate settlements with the plaintiff independently." 140

131196 U.S. 375 (1905) (livestock oligopsony).

132334 U.S. 219 (1948) (sugar beet oligopsony).

133352 U.S. 445 (1957) (professional football labor oligopsony).

134 See generally Roger D. Blair \& Jeffrey L. Harrison, Antitrust Policy and Monopsony, 76 CORNELL L. REV. 297 (1991); Michael C. Naughton, Buyer Power Under Attack: Recent Trends in Monopsony Cases, 18 ANTITRUST 81 (2004); Gregory J. Werden, Monopsony and the Sherman Act, 74 ANTITRUST L.J. 707 (2007).

135 See 1 Antitrust Law DeVElopments, supra note 9, at 81-82.

136462 F. Supp. 685 (M.D. Fla. 1978), aff'd, 650 F.2d 617, 620-21, 622 (5th Cir. 1981) (Unit B) (affirming the grant of summary judgment to the extent it denied injunctive relief).

137621 F. Supp. 1122 (D. Del. 1985) (Caleb Wright, J.).

138 Gould, 462 F. Supp. at 690-91; Lemelson, 621 F. Supp. at 1131. As Professor Joshua Wright recently noted, "[p]erhaps the Chicago School's most important and visible victory has been the continual narrowing of the per se rule, which, after Leegin lifted the prohibition on minimum resale price maintenance, exists only in naked price-fixing cases and, in a weakened form, in tying cases." Joshua D. Wright, The Roberts Court and the Chicago School of Antitrust: The 2006 Term and Beyond, 3 COMPETITION POL'Y INT'L 25 (2007); accord Andrew I. Gavil, Antitrust Bookends: The 2006 Supreme Court in Historical Context, 22 ANTITRUST 21, 21-22 (20072008) ("Per se rules have been supplanted by nuanced, fact-intensive inquiries informed by economic principles and hungry for complex economic evidence."); Roundtable Discussion: The Antitrust Legacy of the Rehnquist-O'Connor Court, 20 ANTITRUST 8, 9 (2006) ("One of the most dramatic doctrinal themes to emerge in the Rehnquist/O'Connor era is an express retreat from per se rules and greater reliance on reasonableness standards. This pattern runs through the Court's horizontal restraint cases, the vertical nonprice cases and, in State Oil v. Khan, treatment of maximum resale price maintenance.") (quoting FTC Commissioner William E. Kovacic).

For example, the Supreme Court has rejected efforts to expand the per se condemnation of group boycotts beyond the type of direct attacks on competition highlighted by Klor's and Radiant Burner. Specifically, in the Northwest Wholesale Stationers case, 472 U.S. 284 (1985), the Court overturned an appeals court's imposition of per se liability against an office supply purchasing cooperative that had expelled a member retailer for failing to give notice of a change in its ownership. $I d$. at 286-88. Noting that purchasing cooperatives can enhance competition by allowing smaller retailers to enjoy economies of scale in supply purchasing and warehousing, and that "[d]isclosure rules" of the type used to justify the challenged expulsion "may well provide the cooperative with a needed means for monitoring the creditworthiness of its members," the Court held that a cooperative's decision to expel a member should generally be analyzed under the rule of reason. Id. at 295-97. It expressly distinguished the per se condemnation triggered in Klor's and Radiant Burner, categorizing the agreements in those cases as "joint efforts by a firm or firms to disadvantage competitors by either directly denying or persuading or coercing suppliers or customers to deny relationships the competitors need in the competitive struggle." Id. at 294 (internal quotation marks omitted). Thus, according to the Court, a purchasing cooperative's expulsion decision does not warrant per se analysis unless "some showing [is] made that the cooperative possesses market power or unique access to a business element necessary for effective competition." Id. at 298; see also id. at 296-97 ("Unless the cooperative possesses market power or exclusive access to an element essential to effective competition, the conclusion that expulsion is virtually always likely to have an anticompetitive effect is not warranted. Absent such a showing with respect to a cooperative buying arrangement, courts should apply a rule-of-reason analysis.”) (citations omitted).

139 Gould, 462 F. Supp. at 691; Lemelson, 621 F. Supp. at 1131

140 Lemelson, 621 F. Supp. at 1131 (emphasis added); see also id. (recounting that, in Jones Knitting, Judge Wright had "reasoned that any restriction on the freedom of the participants to negotiate with plaintiff, no matter how slight, fell within the blanket prohibition on concerted refusals to deal") (emphasis added). 
961 The Jones Knitting group boycott analysis, even when relaxed to a rule-of-reason approach (as in Gould and Lemelson), mistakes a basic fact about patent-based rights to exclude others from using a technology. Patent rights are probabilistic. As a result, an analogy to a buyer cartel for a commodity is quite misguided. Indeed, within this incorrect framework, the more durable the agreement, the more likely it is to be unlawful. Viewed correctly in the research joint venture framework, however, the ancillary provisions that prevent a patent-defense-bloc from unraveling soon after it begins restrain the license market no more than is needed to permit the venture to achieve its procompetitive goala robust test of the patent's validity and scope.

\section{CONCLUSION}

962 More than a century ago, Holmes urged that "[w]e must think things not words, or at least we must constantly translate our words into the facts for which they stand, if we are to keep to the real and the true." 141 Not because words lack force; he acknowledged they have it. ${ }^{142}$ Rather, "inasmuch as the real justification of a rule of law, if there be one, is that it helps to bring about a social end which we desire ... those who make and develop the law should have those ends articulately in their minds." 143

963 What, then, of a patent-defense bloc? Generally, when competitors collaborate to generate information that benefits all of them in later competition, but that no one of them will pay for alone, antitrust law recognizes that the venture fosters socially valuable competition. A probabilistic patent's judicial status and scope is, in the end, simply more information. Antitrust law should not block competing accused infringers from cooperating effectively to generate that information.

141 Oliver Wendell Holmes, Law in Science and Science in Law, 12 HARV. L. REV. 443, 460 (1899). Holmes sought to underscore "the need of scrutinizing the reasons for the rules which we follow, and of not being contented with hollow forms of words merely because they have been used very often and have been repeated from one end of the union to the other." Id.

${ }_{142} I d$. at 455 ("I am immensely struck with the blind imitativeness of man when I see how a doctrine, a discrimination, even a phrase, will run in a year or two over the whole English-speaking world.”).

${ }^{143} I d$. at 460. 